\title{
Assessment of efficiency and potentiality of agricultural resources in Central Asia
}

\author{
ZHANG Jiaoyou ${ }^{1,2}$, CHEN Yaning ${ }^{1}$, LI Zhi $^{1}$ \\ 1. State Key Laboratory of Desert and Oasis Ecology, Xinjiang Institute of Ecology and Geography, CAS, \\ Urumqi 830011, China; \\ 2. University of Chinese Academy of Sciences, Beijing 100049, China
}

\begin{abstract}
This paper quantitatively analyzes the utilization efficiency of agricultural resources in Central Asia by calculating the consumption coefficient of the main resources, including arable land, water and fertilizers. The results of these investigations reveal the following: (1) The average consumption coefficients of cultivated land resources in Central Asia are much higher than the world average value of up to $7.74 \mathrm{~m}^{2} / \mathrm{kg}$, which is 3.6 times that of China, suggesting that the cultivated land resource consumption coefficient of cultivated land resource utilization efficiency is low in the Central Asian region. (2) Up to $80 \%$ of available water resources are used for agriculture irrigation. The average agricultural water consumption in Central Asia is about $9.43 \mathrm{~m}^{3} / \mathrm{kg}$, or nearly 9.3 times the average value elsewhere in Asia, indicating that agricultural water use efficiency in this region is very low and water resources are wasted. (3) The fertilizer consumption coefficient in Central Asia is $0.035 \mathrm{~kg} / \mathrm{kg}$, which is close to the world average, but the utilization efficiency of fertilizer is relatively high. Therefore, in the future development of agriculture, Central Asia should pay more attention to the management of agricultural water resources in order to improve the utilization efficiency of these resources as well as that of arable land.
\end{abstract}

Keywords: Central Asia; agricultural resources; consumption coefficient; use efficiency

\section{Introduction}

Around the world, recent population expansion, rapid economic growth, rising biofuel production and increasing pollution levels are exerting tremendous pressure on land and fresh water resources that can best be described as limited (Godfray et al., 2010; Gopalakrishnan et al., 2009; Hoogerbrugge and Fresco, 2016; Schneider et al., 2011; Zhao et al., 2015). Agricultural land and water are the two most critical resources for life and food. Global per capita agricultural land is around 0.7 ha, accounting for $37.9 \%$ of the world's per capita land area. Moreover, per capita freshwater withdrawal amounts are approximately $552.1 \mathrm{~m}^{3} /$ year,

Received: 2018-01-16 Accepted: 2018-04-02

Foundation: The Strategic Priority Research Program of the Chinese Academy of Sciences, No.XDA19030204; National Natural Science Foundation of China, No.41630859

Author: Zhang Jiaoyou (1991-), Master Candidate, specialized in efficiency evaluation for water resources of Central Asia. E-mail: zhangjiaoyou2018@163.com 
of which $70 \%$ is used for agricultural purposes (Chen et al., 2018). At the same time, the factors of increasing water scarcity and competition for water and land from agricultural and non-agricultural sectors are driving the need to improve crop water productivity and to guarantee adequate food for future generations with the same or less water and land than that is currently available (Platonov et al., 2008; Smith, 2000). Therefore, research on the utilization efficiency of agricultural resources has important theoretical and practical significance for ensuring current and future food security, improving the ecological environment, and increasing cereals output (Barakat et al., 2013).

The term "agricultural resources" mainly refers to the natural and socio-economic resources involved in natural and economic reproduction (Revelle, 1976; Fernandez, 2006; Mittu and Chauhan, 2015). Assessment of agricultural resources efficiency is an important aspect of scientific research resources, as it promotes the combination of theory and practice of scientific research resources, while realizing the efficient use of regional agricultural resources towards sustainable socio-economic development. In general, increased yields mainly result from greater inputs of agricultural resources such as fertilizer, water, pesticides, technology, and so on (Tilman et al., 2002), indicating that these resources have an extremely important influence on the output and sustainable development of agriculture. However, given the complexity of agricultural resources contents and their interaction and interdependency, they need to be evaluated from a broader perspective that includes resource, social, economic and ecological benefits as well as intergenerational interests. This evaluation involves numerous technical difficulties in the comprehensive and accurate estimation and evaluation of resource utilization efficiency (Xie et al., 1998).

The current exponential growth levels of the global population requires finding a means to ensure future food security, reduce the impact of agriculture on the environment, and give full play to the potential of increasing food. Based on their use of the latest geospatial data and models, Foley et al. (2011) proposed measures to stop agricultural expansion, increase food production, improve crop productivity, improve diet, and reduce waste. They also evaluated how these measures could benefit both food production and environmental sustainability. Davis et al. (2016) presented a quantitative multi-metric assessment of how changes in efficiency and dietary patterns can combine to increase food supply and minimize environmental impacts from agriculture, estimating that $776 \mathrm{~m}^{3} \mathrm{H}_{2} \mathrm{O}, 15.3 \mathrm{~kg} \mathrm{~N}, 299 \mathrm{~kg} \mathrm{CO}$ and 0.85 ha are required annually to support an average global diet. Their assessment was that average footprint intensities will need to improve substantially (e.g., $\mathrm{H}_{2} \mathrm{O}: 65 \% ; \mathrm{N}: 85 \%$; greenhouse gas emissions: $72 \%$; land: $97 \%$ ) if future increases in environmental burdens are to be prevented. However, as these researchers only consider consumption patterns from a global perspective, they avoid many of the difficulties associated with obtaining accurate footprint intensity values.

In Central Asia, water is becoming an increasingly important limiting factor of agricultural development. In order to find solutions to solve the region's water management problems, Abdullaev (2004) calculated the water use efficiency of the water supply and evapotranspiration. The results of that study showed that there is great potential for increasing average values of water productivity within the basin, and that farmers and water managers are capable of achieving higher levels of production. To date, research on the utilization efficiency of agricultural resources in China has focused more on the selection of in- 
dexes and methods, which usually include ratio analysis, production function, Data Envelopment Analysis, factor-energy evaluation models, etc. In China, agricultural water production (WP) also has been recognized as an important indicator of agricultural water management. Cai et al. (2011) assessed the WP for irrigated (WPI) and rain-fed (WPR) crops in the Yellow River Basin, and this study shows that the yield of irrigation crops is higher than that of rain-fed crops, however, WPI is less than WPR. At the same time, it is crucial to consider not only the effective economic output, but also the negative effect output when measuring the efficiency of resource utilization. Xie et al. (1998) calculated and evaluated the consumption of major agricultural resources (e.g., fresh water and fertilizers) in different countries and regions around the world, concluding that the utilization of agricultural resources in China is inefficient and needs to be drastically improved.

Central Asia is located in the hinterland of Eurasia and includes the five "stan" countries of Kazakhstan (KAZ), Kyrgyzstan (KGZ), Tajikistan (TJK), Turkmenistan (TKM) and Uzbekistan (UZB). These five nations are part of the "One Belt and One Road" region, of which agriculture is traditionally the leading industry. In Central Asia, water is the most critical factor in economic social development and is also the main resource in agricultural production (Chen et al., 2016; Deng et al., 2017; Li et al., 2017). In our study, to calculate and assess the utilization efficiency of arable land, water and fertilizers as agricultural resources, we apply a simple and operable ratio analysis method, and then use the resource consumption coefficient. The main purpose of this paper is to provide a scientific basis for the in-depth assessment of the development potential of resources in Central Asia to improve the efficiency of agricultural resources utilization and to realize sustainable and efficient utilization of regional agricultural resources.

\section{Study areas and methods}

\subsection{General situation of the study region}

The research area of this paper is Central Asia (Figure 1), which is comprised of Kazakhstan (KAZ), Kyrgyzstan (KGZ), Tajikistan (TJK), Turkmenistan (TKM) and Uzbekistan (UZB). The Central Asian region is about 4 million square kilometers, and is located at $35^{\circ} 08^{\prime} \mathrm{N}-55^{\circ} 25^{\prime} \mathrm{N}$ and $46^{\circ} 28^{\prime} \mathrm{E}-87^{\circ} 29^{\prime} \mathrm{E}$. The eastern portion of Central Asia is adjacent to China's Xinjiang Uygur Autonomous Region, the western portion borders the Caspian Sea, the northern area borders Russia, and the southern borders Iran and Afghanistan. Being situated in the hinterland of Eurasia, Central Asia has a temperate continental climate featuring very little precipitation and significant evaporation, which is typical of arid and semi-arid interior regions (Zhang et al., 2017). Elevations in the study area are generally low in the west and high in the east, ranging from $28 \mathrm{~m}$ below sea level (the Caspian Sea in western Turkmenistan and Kazakhstan) to $4000 \mathrm{~m}$ above sea level in the eastern Tianshan Mountains. In fact, the major rivers originate in the eastern and southeastern Tianshan Mountains, whereas to the north there is mostly grassland, plains and hills. The main transboundary rivers in Central Asia include the Amu Darya, the Syr Darya, the Ergis River, and the Ili River, while the major lakes are the Aral Sea, Balkhash Lake, Issy-Kul Lake, and Zaisan Lake.

Given the region's aridity, the primary form of agriculture in Central Asia is irrigated farming, with some rainfed farming occurring in the north. Irrigated farming accounts for 
the majority of water use in the region, consuming almost $80 \%-85 \%$ of available water resources (Abdullaev, 2004). Irrigated agriculture is concentrated in the Aral Sea basin, but the land productivity of the entire basin is very low, especially in relation to water efficiency. In contrast, KAZ, KGZ, TJK, TKM and UZB have abundant agricultural resources, such as light, heat, water and soil resources, but the space allocation of their agricultural resources is uneven. For instance, TJK and KGZ have the most water, KAZ has the most abundant land resources, and UZB and TKM have superior soil, topography, labor and other natural conditions and social conditions, due to their location in the middle and lower reaches of the Amu Darya and Syr Darya, Central Asia's largest inland rivers.

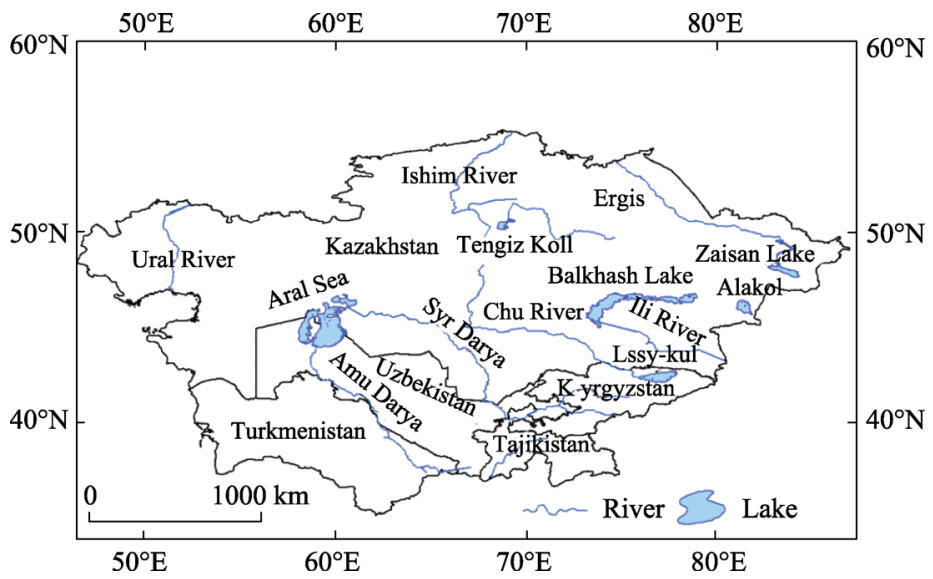

Figure 1 Location of Central Asia

\subsection{Data}

The data used in this study come from the United Nations Food and Agriculture Organization (FAO: http://www.fao.org) and World Development Indicators (WDI) published by the World Bank (https://data.worldbank.org/indicator). They show the total population of the five countries of Central Asia (2014), arable land (2014), arable land (ha/person) (2014), land under cereal production (1992-2014), cereal production (1992-2014), agriculture of total freshwater withdrawal (2007-2014), industrial total freshwater withdrawal (2007-2014), total domestic freshwater (2007-2014), total annual freshwater withdrawals (2014), fertilizer consumption (2002-2014), and the value added by agriculture (2014).

\subsection{Method}

This paper mainly uses the ratio of agricultural resource inputs (arable land, agricultural water and fertilizer) and cereal production to analyze the consumption coefficient and efficiency of the main agricultural resources in Central Asia. The following equations are applied (Xie et al., 1998):

(1) The cultivated land resource consumption coefficient, expressed as:

$$
\text { Clre }=\frac{\text { Fla } \times 10000}{O g}
$$

where Clre is the consumption coefficient of cultivated land resources, Fla is the area of arable land (ha), and $O g$ is total cereal production $(\mathrm{kg})$. 
(2) Agricultural water consumption coefficient, expressed as:

$$
A w e c=\frac{A w u a \times A w u c}{O g}
$$

where Awec is the agricultural water consumption coefficient, Awua is the annual fresh water resource extraction $\left(\mathrm{m}^{3}\right), A w u c$ is the proportion of water used in agriculture, and $O g$ is the total cereal production $(\mathrm{kg})$.

(3) Fertilizer consumption coefficient, expressed as:

$$
F e c=\frac{F a u a}{O g}
$$

where $\mathrm{Fec}$ is the fertilizer consumption coefficient; Faua is fertilizer consumption (in $\mathrm{kg}$ ), and $O g$ is the total cereal production $(\mathrm{kg})$.

\section{Results and discussion}

\subsection{Arable land resources consumption coefficient and utilization efficiency}

Arable land resources comprise the most basic natural resources needed for agricultural production (Lenhardt et al., 2017; Visser, 2016). There is approximately $13 \times 10^{8} \mathrm{hm}^{2}$ of cultivated land in the world, feeding a population of about $60 \times 10^{8}$; the per capita arable area is about $0.225 \mathrm{hm}^{2}$ (Xie et al., 1998). The geographical landscape of Central Asia is mainly desert and grassland, with a desert area comprising more than $100 \times 10^{4} \mathrm{~km}^{2}$. Overall, the amount of arable land in the five Central Asian countries is relatively small. According to World Bank data (Table 1), the populations of these countries are steadily increasing and currently stand at $67.71 \times 10^{6}$. Uzbekistan and Kazakhstan account for $45.43 \%$ and $25.53 \%$ of the Central Asian total population, respectively, followed by Tajikistan (12.35\%), Kyrgyzstan $(8.62 \%)$ and Turkmenistan $(8.07 \%)$. The rise in population has led to a per capita reduction in arable land resources, making the per person areal area of Central Asia smaller than that of the world average. As of 2014, Kazakhstan's arable land covered about 10.89\% of its total land area, giving an arable area of about $1.700 \mathrm{hm}^{2}$ per capita; Kyrgyzstan's arable land covered about $6.68 \%$ of its land area, giving an arable area of about $0.219 \mathrm{hm}^{2}$ per capita; Tajikistan's arable land covered about $5.26 \%$ of its land area, giving a per capita areal area of about $0.087 \mathrm{hm}^{2}$; Turkmenistan's arable land covered about $4.13 \%$ of its land area,

\begin{tabular}{|c|c|c|c|c|c|c|}
\hline \multirow{3}{*}{ Country } & \multicolumn{2}{|c|}{ Population } & \multicolumn{4}{|c|}{ Arable land } \\
\hline & Total & $\begin{array}{c}\text { Percentage of total } \\
\text { population of } \\
\text { Central Asia }\end{array}$ & Land area & $\begin{array}{c}\text { Arable land } \\
\text { area }\end{array}$ & $\begin{array}{c}\text { Percentage of } \\
\text { land area }\end{array}$ & $\begin{array}{l}\text { Per person of } \\
\text { arable land }\end{array}$ \\
\hline & $10^{6}$ person & $\%$ & $\mathrm{~km}^{2}$ & $\mathrm{~km}^{2}$ & $\%$ & ha/person \\
\hline KAZ & 17.29 & 25.53 & 2699700 & 293950 & 10.89 & 1.700 \\
\hline KGZ & 5.83 & 8.62 & 191800 & 12806 & 6.68 & 0.219 \\
\hline TJK & 8.36 & 12.35 & 138786 & 7300 & 5.26 & 0.087 \\
\hline TKM & 5.47 & 8.07 & 469930 & 19400 & 4.13 & 0.355 \\
\hline UZB & 30.76 & 45.43 & 425400 & 44000 & 10.34 & 0.143 \\
\hline Central Asia & 67.71 & 100 & 3925616 & 377456 & 9.62 & 0.538 \\
\hline
\end{tabular}

Table 1 Population and arable land of the five Central Asian countries (2014) 
giving an arable area of about $0.355 \mathrm{hm}^{2}$ per capita; and Uzbekistan's arable land covered about $10.34 \%$ of its land area, giving an arable area of about $0.143 \mathrm{hm}^{2}$ per capita. Therefore, in order to deal appropriately with the pressure of population growth, these countries need to constantly improve their utilization efficiency of arable land resources to meet the food needs of the projected population increase in the future.

The consumption coefficient of arable land resources is the ratio of grain seeding area to grain yield, or the amount of arable land needed to produce one kilogram of food. The efficiency coefficient of cultivated land resources is the reciprocal of the consumption coefficient of arable land, indicating the grain yield per unit area. The cereal concept defined by FAO refers to grains such as wheat, rice, maize and barley. In addition, cereal yield is measured as kilograms per hectare of harvested land, while production data on cereals relate to crops harvested for dry grain only. Thus, in this paper, grain yield is cereal yield, and arable area is harvested land area. The average consumption coefficient of arable land resources in Central Asia is 7.74, which is higher than the world average and 3.6 times that of China's arable land resources (Xie et al., 1998). Of the five Central Asian countries (Figure 2), Kazakhstan has the highest arable land consumption coefficient, with an average consumption coefficient of 10.35 . The reason for this relatively high level could be that because Kazakhstan has relatively more arable land resources and it uses more extensive production methods, thus causing more arable land per unit of grain consumed and making less efficient use of arable land. In contrast, in Kyrgyzstan and Tajikistan, which are located in the southeastern part of Central Asia, about $90 \%$ of the land area is mountainous and therefore arable land resources are limited. As a result, intensive cultivation methods are used in these two countries, making the consumption coefficients of arable land resources relatively low. The arable land consumption coefficients in Turkmenistan and Uzbekistan are all lower than other countries in Central Asia, but they are still quite high compared to China, which is only 2.15 (Xie et al., 1998).

The total arable land resource consumption coefficients of the five Central Asian countries reveal a significant downward trend (Figure 3). As can be seen, the consumption coefficient of cultivated land resources in

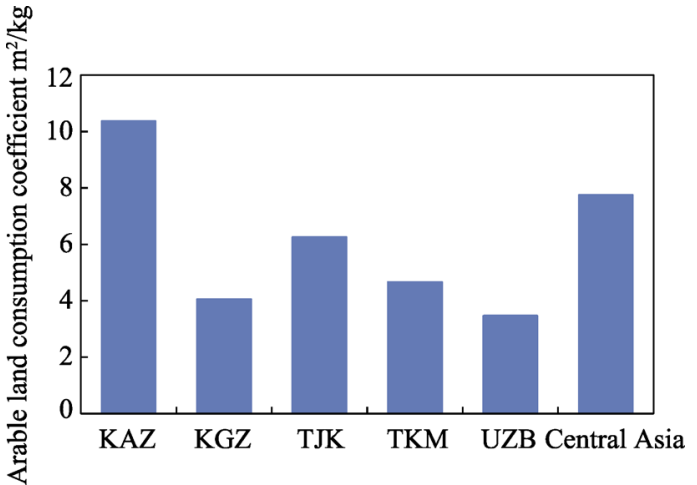

Figure 2 Consumption coefficient of arable land in the five countries of Central Asia

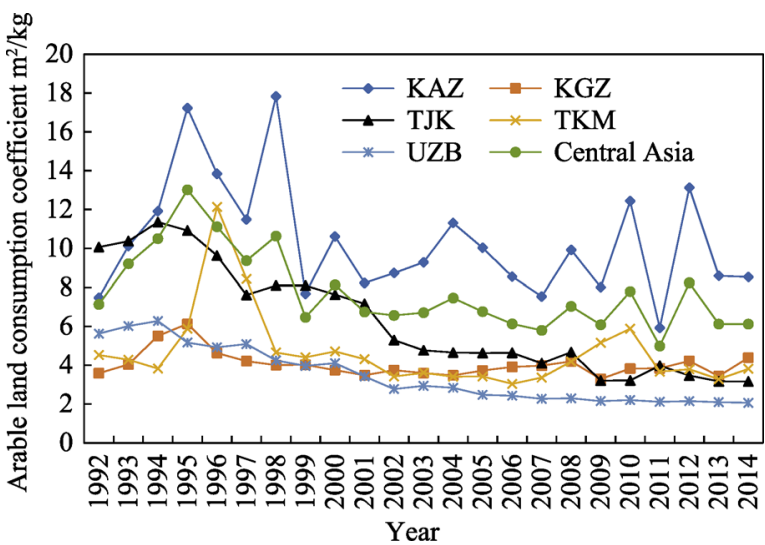

Figure 3 Changing trends of cultivated land resource consumption coefficients in Central Asia in 1992-2014 
the entire Central Asian region declined from 13.01 in 1995 to 6.12 in 2014. This indicates that the utilization efficiency of arable land resources in Central Asia has gradually improved since the break-up of the Soviet Union. Improvements in efficiency come from the choice of better grain varieties and fertilizers, along with changes to cultivation systems and the adoption of advanced management methods.

\subsection{Agricultural water consumption coefficient and utilization efficiency}

Agricultural water is the most important means of water resource utilization in all five Central Asian countries (Kulmatov, 2014; Thevs et al., 2015), with irrigation being the most important means of delivering water to farmland ( Kitamura et al., 2000; Abdullaev et al., 2010). In reviewing Table 2 data on water withdrawal by sector, we can see that water for agricultural purposes accounted for the largest withdrawal, with Kazakhstan using $66 \%$ for farming, Kyrgyzstan using 93\%, Tajikistan 91\%, Turkmenistan 94\%, and Uzbekistan 90\% (Table 2). Overall, the table shows that agriculture is the most water-intensive industry, with more than $80 \%$ of all available water being used in farming.

Table 2 Water withdrawal by sector (2014)

\begin{tabular}{|c|c|c|c|c|c|c|}
\hline \multirow{3}{*}{ Country } & \multicolumn{2}{|c|}{ Industries } & \multicolumn{2}{|c|}{ Municipalities } & \multicolumn{2}{|c|}{ Agriculture } \\
\hline & Volume & $\begin{array}{l}\text { Percentage of } \\
\text { total }\end{array}$ & Volume & $\begin{array}{l}\text { Percentage of } \\
\text { total }\end{array}$ & Volume & $\begin{array}{c}\text { Percentage of } \\
\text { total }\end{array}$ \\
\hline & $10^{9} \mathrm{~m}^{3}$ & $\%$ & $10^{9} \mathrm{~m}^{3}$ & $\%$ & $10^{9} \mathrm{~m}^{3}$ & $\%$ \\
\hline KAZ & 6.26 & 29.63 & 0.88 & 4.15 & 14.00 & 66.23 \\
\hline KGZ & 0.34 & 4.20 & 0.22 & 2.80 & 7.45 & 93.01 \\
\hline TJK & 0.41 & 3.55 & 0.65 & 5.63 & 10.44 & 90.86 \\
\hline TKM & 0.84 & 3.00 & 0.75 & 2.70 & 26.36 & 94.31 \\
\hline UZB & 1.50 & 2.68 & 4.10 & 7.32 & 50.40 & 90.00 \\
\hline Central Asia & 9.35 & 7.50 & 6.60 & 5.30 & 108.65 & 87.21 \\
\hline
\end{tabular}

The water resources available in Central Asia are mainly surface water, groundwater and recycled water (Karen, 2013), and the distribution of water resources is extremely uneven (Table 3). Tajikistan and Kyrgyzstan, located upstream of the Aral Sea Basin, provide 32.6\% and $25.2 \%$, respectively, of domestic renewable freshwater resources (mainly surface water produced by rivers and precipitation). The total water resources of the two countries comprises more than $57 \%$ of the entire Central Asian region, but they only withdraw less than $11 \%$ of the total water available. Meanwhile, Tajikistan only withdraws $18 \%$ of its total water resource production, and Kyrgyzstan withdraws $16 \%$. However, the total water resources provided by Kazakhstan, Turkmenistan and Uzbekistan, which are located in the lower reaches of the Aral Sea Basin, are only about 42\% (Kazakhstan 33.1\%, Turkmenistan 0.7\%, Uzbekistan $8.4 \%$ ) of the overall water resources in Central Asia, yet these three countries withdraw more than $84 \%$ of the total water used in the region. Turkmenistan's water consumption is 19.9 times that of its domestic water resources, and Uzbekistan's water consumption is 3.4 times. Hence, these water resource-poor countries make up for their own water shortages through upstream water supplies, making them heavily dependent on water coming from upstream countries (Lerman, 2008; Abdullaev et al., 2009). 
Table 3 Water resources and water usage in Central Asia (2014)

\begin{tabular}{ccccccc}
\hline \multirow{2}{*}{ Country } & $\begin{array}{c}\text { Total fresh- } \\
\text { water in } \\
\text { country }\end{array}$ & $\begin{array}{c}\text { Percentage of } \\
\text { total fresh- } \\
\text { water in } \\
\text { Central Asia }\end{array}$ & $\begin{array}{c}\text { Water with- } \\
\text { drawal by } \\
\text { country }\end{array}$ & $\begin{array}{c}\text { Water with- } \\
\text { drawal of } \\
\text { total fresh- } \\
\text { water }\end{array}$ & $\begin{array}{c}\text { Water with- } \\
\text { drawal to } \\
\text { total with- } \\
\text { drawal in } \\
\text { Central Asia }\end{array}$ & $\begin{array}{c}\text { Water with- } \\
\text { drawal to } \\
\text { total water } \\
\text { resources in } \\
\text { Central Asia }\end{array}$ \\
\cline { 2 - 7 } & $10^{9} \mathrm{~m}^{3}$ & $\%$ & $10^{9} \mathrm{~m}^{3}$ & $\%$ & $\%$ & $\%$ \\
KAZ & 64.35 & 33.09 & 21.14 & 32.85 & 16.97 & 10.87 \\
KGZ & 48.93 & 25.16 & 8.01 & 16.36 & 6.43 & 4.12 \\
TJK & 63.46 & 32.63 & 11.49 & 18.11 & 9.22 & 5.91 \\
TKM & 1.41 & 0.72 & 27.95 & 1989.32 & 22.43 & 14.37 \\
UZB & 16.34 & 8.40 & 56.00 & 342.72 & 44.95 & 28.79 \\
Central Asia & 194.49 & 100 & 124.59 & 64.06 & 100 & 64.06 \\
\hline
\end{tabular}

The agricultural water consumption coefficient refers to the amount of water consumed per $1 \mathrm{~kg}$ of cereal production, while the reciprocal of agricultural water consumption coefficient is the efficiency of agricultural water resources utilization. It is necessary to use agricultural irrigation water consumption data for cereal irrigation water in order to analyze the agricultural water consumption coefficient. However, due to limitations in data collection, we have to use agricultural water in this study to analyze water consumption coefficients. Table 4 depicts agricultural water consumption coefficients in Central Asia, showing that the average agricultural water consumption coefficient is 9.43. Compared to other regions in the world, agricultural water consumption coefficients in Central Asia are much higher. The natural environment of Central Asia is similar to that of western China, but the water consumption coefficient of agriculture is nine times that of western China, indicating that the agricultural water efficiency is very low in Central Asia. Of the five Central Asian countries, Kazakhstan has the lowest consumption coefficient of agricultural water resources (1.166). This coefficient is lower than the Central Asian average and also lower than the averages of Egypt and Japan. Tajikistan and Uzbekistan are in second and third place, respectively, while Turkmenistan has the largest consumption of agricultural water. As can be seen, the five countries are gradually reducing their water consumption coefficients while at the same time slowly increasing their agricultural water use efficiency (Figure 4). The water consumption coefficiency in Central Asia is also decreasing from 14.56 in 1997 to 9.43 in 2014.

\subsection{Consumption coefficient and uti- lization efficiency of fertilizer}

Fertilizer is an important resource in agricultural production, with nitrogen, potash and phosphate fertilizers all playing crucial roles in grain production (Jallah et al., 1991). Because fertilizer improves

Table 4 Comparison of water consumption coefficient in Central Asia with that of other regions (Xie et al., 1998)

\begin{tabular}{lc}
\hline \multicolumn{1}{c}{ Region } & $\begin{array}{c}\text { Water consumption } \\
\text { coefficients }\left(\mathrm{m}^{3} / \mathrm{kg}\right)\end{array}$ \\
\hline Asia & 1.014 \\
Africa & 0.684 \\
North America & 0.33 \\
South America & 0.331 \\
Europe & 0.225 \\
Egypt & 2.638 \\
Japan & 1.946 \\
China & 1.102 \\
Western China & 1.105 \\
Central Asia & 9.434 \\
\hline
\end{tabular}


cereal production, the amount of fertilizer invested in agriculture in Central Asia is also increasing year by year (Vyshpolsky et al., 2010). (Note that, due to data limitations, Turkmenistan is excluded from these data.) According to the input level of fertilizer per unit of cultivated area, $1.97 \mathrm{~kg}$ of fertilizer was invested per hectare in Central Asia in 2002, with the amount of fertilizer applied per hectare increasing to $82.68 \mathrm{~kg}$ in 2014. This means that the amount of fertilizer applied

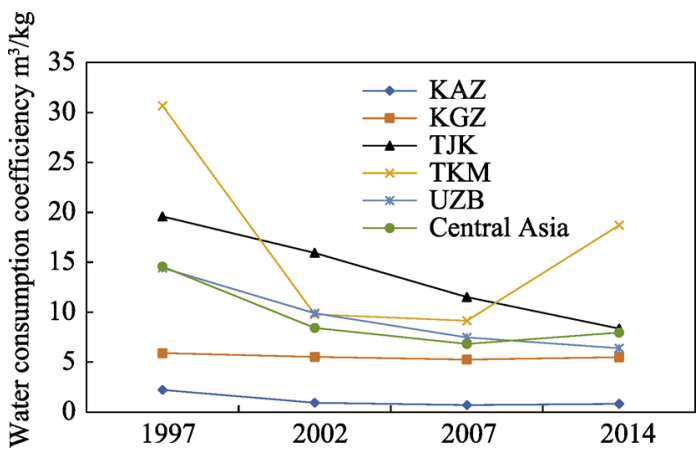

Figure 4 Trend of agricultural water consumption coefficients and efficiency in Central Asia in 1997-2014 has increased exponentially (around 82 times) over a short period. The increased fertilizer use and grain yield also brought serious ecological pollution, such as soil hardening, polluting of groundwater resources, and decline in crop quality (Kotlyakov, 1991). In the five Central Asian states of Uzbekistan, Kyrgyzstan, Tajikistan, Kazakhstan, and Turkmenistan, approximately $50 \%$ of the irrigated land is affected by salinization (Kitamura et al., 2000; Conrad et al., 2013; Tanirbergenov et al., 2016). Among the four countries under study in this section, Uzbekistan has experienced the worst impacts due to heavy fertilizer application and soil salinization intensity, with soil salinization areas expanding from 50\% in 1994 to $65.9 \%$ in 2001 ( $\mathrm{Ji}$ et al., 2009).

For every $1 \mathrm{~kg}$ of cereal produced in Central Asia, $0.035 \mathrm{~kg}$ of fertilizer is consumed. This is close to the average world level. The average consumption of $1 \mathrm{~kg}$ of cereal in China is $0.069 \mathrm{~kg}$ of fertilizer, while the average consumption in the West is $0.078 \mathrm{~kg}$, and the average consumption in the US is $0.022 \mathrm{~kg}$. Thus, the rate of fertilizer consumption in Central Asia is very close to the world average, below the average level in China and the West, and above the average in the US.

In a horizontal comparison of Central Asian nations (excluding Turkmenistan), the consumption coefficient of fertilizer input shows the highest fertilizer consumption coefficient, which is 0.079 . Tajikistan and Kyrgyzstan have a fertilizer consumption coefficient of 0.038 and 0.018 , respectively, and Kazakhstan has the lowest fertilizer consumption, with a factor

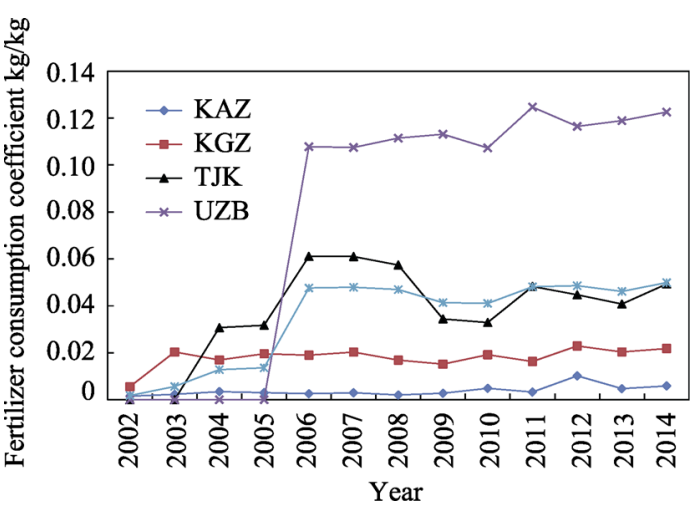

Figure 5 Trends in fertilizer consumption coefficients in Central Asia in 2002-2014 of 0.004 , which is well below the world average. As can be seen from Figure 5, the consumption coefficient of fertilizer consumption in Central Asia increased between 2002 and 2006. In other words, the amount of fertilizer per unit of grain output has gradually increased. From 2006 to 2014, fertilizer consumption coefficients were more stable, showing only small fluctuations. This indicates that the amount of fertilizer per grain output was more stable from 2006 to 2014. 


\subsection{Utilization potential of agricultural resources in Central Asia}

Although Central Asia is dominated by agriculture and there are many natural resources and social resources devoted to agricultural development, the contribution of agriculture to the countries' national income is relatively small. According to World Bank data, the value added by agriculture in Kazakhstan is only $4.69 \%$ of GDP; in Kyrgyzstan, this amount is $17.11 \%$; in Tajikistan, it is $27.25 \%$; in Turkmenistan, it is $8.29 \%$; and in Uzbekistan, the value added by agriculture is $18.79 \%$ of GDP. By combining the main agricultural resource consumption coefficient and utilization efficiency of the previous analysis, it can be concluded that the productivity level of the primary agricultural resources in Central Asian region is low. At the same time, however, agricultural development in the region has immense potential in both land and water resources. Table 5 shows Central Asia's main agricultural resources (water, fertilizer) and cereal production arable land per hectare. As can be seen, for every hectare of arable land, Kazakhstan has the least amount of water and fertilizer. Although Kazakhstan has a lower per unit area yield, its water resources are the most efficient and its fertilizer use is the lowest. In addition, Kazakhstan has the largest total grain output and grain exports. Specifically, cereal production doubled in 2011 , with about $3 \times 10^{7}$ tonnes of cereal and $16 \times 10^{7}$ tonnes of export. Meanwhile, Uzbekistan has the highest cereal production per hectare, but its water use efficiency and fertilizer usage are also the highest. Improvements in agricultural productivity are the key determinants in development, as such improvements allow countries to satisfy their basic agricultural needs sooner and thus free up resources for industrialization (Restuccia et al., 2008). Therefore, it is important to fully develop the agricultural resource potential of Central Asian countries in order to accelerate the utilization efficiency of agricultural resources and promote the economic development in Central Asia.

Table 5 Main agricultural resources input and quantity of grain output

\begin{tabular}{ccccc}
\hline & & Input & Output \\
\cline { 2 - 5 } Country & Arable land & Water & Fertilizer & Production \\
\cline { 2 - 5 } & $(\mathrm{ha})$ & $\left(\mathrm{m}^{3}\right)$ & $(\mathrm{kg})$ & $(\mathrm{kg})$ \\
\hline KAZ & 1 & 960.28 & 6.84 & 1172.89 \\
KGZ & 1 & 12502.43 & 49.57 & 2276.25 \\
TJK & 1 & 26459.25 & 156.24 & 3167.92 \\
TKM & 1 & 49111.46 & $*$ & 2627.01 \\
UZB & 1 & 30857.77 & 592.16 & 4831.32 \\
Central Asia & 1 & 6124.33 & 65.28 & 1635.13 \\
\hline
\end{tabular}

* means no data

\section{Conclusions}

Through the analysis of the main agricultural resource consumption coefficient and utilization efficiency for Central Asia, we can conclude the following:

(1) In Central Asia, per capita cultivated land area is decreasing from 0.834 in 1992 to 0.538 in 2014, the consumption coefficient of arable land resources (7.74) is higher than the average level in China (2.15), and the utilization efficiency of cultivated land is low. Ka- 
zakhstan has the highest agricultural consumption coefficient (10.35), followed by Tajikistan (6.25), Turkmenistan (4.66), Kyrgyzstan (4.05) and Uzbekistan (3.46). Therefore, it is necessary to protect and improve the arable land resource environment, increase cereal production per hectare, and reduce the consumption coefficient of cultivated land resources.

(2) Agricultural water efficiency is the lowest in the three agricultural resources utilization, and it is far below the world average. Kazakhstan has the lowest consumption coefficient of agricultural water resources (1.166), followed by Kyrgyzstan (5.54), Uzbekistan (9.54) and Tajikistan (13.85). Turkmenistan has the largest consumption of agricultural water (17.07). The reasons for this situation are, first, the high water-intensive crop area is larger; and second, the flood irrigation mode for the irrigation area is far larger than the actual demand, leading to water salinization ecological problems. This situation indicates the need to improve water use efficiency in farming methods and irrigation systems.

(3) Fertilizer consumption is relatively low and close to the world average. Uzbekistan has the highest fertilizer consumption coefficient (0.079), followed by Tajikistan (0.0379) and Kyrgyzstan (0.018). Kazakhstan has the lowest rate of fertilizer consumption and is well below the world average. However, the amount of fertilizer used in Central Asian unit cereals and unit arable land inputs is gradually increasing. Accordingly, the region should be more moderate in its use of chemical fertilizers and strive to develop green agriculture.

\section{References}

Abdullaev I, Fraiture C D, Giordano M et al., 2009. Agricultural water use and trade in Uzbekistan: Situation and potential impacts of market liberalization. International Journal of Water Resources Development, 25(1): 47-63.

Abdullaev I, Kazbekov J, Manthritilake H et al., 2010. Water user groups in Central Asia: Emerging form of collective action in irrigation water management. Water Resources Management, 24(5): 1029-1043.

Abdullaev I, Molden D, 2004. Spatial and temporal variability of water productivity in the Syr Darya Basin, Central Asia. Water Resources Research, 40(8): 379-405.

Barakat M N, Aldoss A A, Elshafei A A et al., 2013. Assessment of genetic diversity among wheat doubled haploid plants using TRAP markers and morpho-agronomic traits. Australian Journal of Crop Science, 7(1): 104-111.

Cai X, Yang Y-C E, Ringler C et al., 2011. Agricultural water productivity assessment for the Yellow River Basin. Agricultural Water Management, 98(8): 1297-1306.

Chen B, Han M Y, Peng K et al., 2018. Global land-water nexus: Agricultural land and freshwater use embodied in worldwide supply chains. Science of the Total Environment, 613/614: 931-943.

Chen Y N, Li W H, Deng H J et al., 2016. Changes in Central Asia's water tower: Past, present and future. Scientific Reports, 6: 35458.

Conrad C, Rahmann M, Machwitz M et al., 2013. Satellite based calculation of spatially distributed crop water requirements for cotton and wheat cultivation in Fergana Valley, Uzbekistan. Global and Planetary Change, 110: 88-98.

Davis K F, Gephart J A, Emery K A et al., 2016. Meeting future food demand with current agricultural resources. Global Environmental Change, 39: 125-132.

Deng H J, Chen Y N, 2017. Influences of recent climate change and human activities on water storage variations in Central Asia. Journal of Hydrology, 544: 46-57.

Fernandez L, 2006. Natural resources, agriculture and property rights. Ecological Economics, 57(3): 359-373.

Foley J A, Ramankutty N, Brauman K A et al., 2011. Solutions for a cultivated planet. Nature, 478(7369): 337-342.

Godfray H C J, Beddington J R, Crute I R et al., 2010. Food security: The challenge of feeding 9 billion people. Science, 327(5967): 812.

Gopalakrishnan G, Negri M C, Wang M et al., 2009. Biofuels, land, and water: A systems approach to sustainabil- 
ity. Environmental Science \& Technology, 43(15): 6094-6100.

Hoogerbrugge I, Fresco L O, 2016. Homegarden Systems: Agricultural Characteristics and Challenges. Inge D Hoogerbrugge \& Louise.

Jallah J K, Mulbah C K, Kiazolu J S et al., 1991. Efficient fertilizer use for increased crop production: The Liberia experience. Fertilizer Research, 29(1): 65-79.

Ji L-L, Abuduwaili, Mubareke A et al., 2009. Comparative analysis of the land water resources exploitation and its safety in the five countries of Central Asia. Journal of Glaciology and Geocryology, 31(5): 960-968. (in Chinese)

Karen F, 2013. Irrigation in Central Asia in Figures. AQUASTAT Survey-2012, FAO Water Reports 39.

Kitamura Y, Yano T, Yasuda S et al., 2000. Water and salt behavior in an irrigation block under rice-based cropping system in Central Asia: Research on water management to prevent secondary salinization in arid land (II). Transactions of the Japanese Society of Irrigation Drainage \& Reclamation Engineering, 68: $183-192$.

Kotlyakov V M, 1991. The Aral Sea Basin: A critical environmental zone. Environment: Science and Policy for Sustainable Development, 33(1): 4-38.

Kulmatov R, 2014. Problems of sustainable use and management of water and land resources in Uzbekistan. Journal of Water Resource and Protection, 6(1): 35-42.

Lenhardt P P, Brãhl C A, Leeb C et al., 2017. Amphibian population genetics in agricultural landscapes: Does viniculture drive the population structuring of the European common frog (Rana temporaria)? Peerj, 5(7): e3520.

Lerman Z, 2008. Agricultural development in Uzbekistan: The effect of ongoing reforms. Discussion Papers.

Li Z, Chen Y N, Fang G H et al., 2017. Multivariate assessment and attribution of droughts in Central Asia. Scientific Reports, 7: 1316.

Mittu B, Chauhan A, 2015. Soil health: An issue of concern for environment and agriculture. Journal of Bioremediation \& Biodegradation, 6(3): 1-4.

Platonov A, Thenkabail P S, Biradar C M et al., 2008. Water Productivity Mapping (WPM) using Landsat ETM+ data for the irrigated croplands of the Syrdarya River Basin in Central Asia. Sensors, 8(12): 8156-8180.

Restuccia D, Yang D T, Zhu X, 2008. Agriculture and aggregate productivity: A quantitative cross-country analysis. Journal of Monetary Economics, 55(2): 234-250.

Revelle R, 1976. The resources available for agriculture. Scientific American, 235(235): 164-178.

Schneider U A, Havlík P, Schmid E et al., 2011. Impacts of population growth, economic development, and technical change on global food production and consumption. Agricultural Systems, 104(2): 204-215.

Smith M, 2000. The application of climatic data for planning and management of sustainable rainfed and irrigated crop production. Agricultural and Forest Meteorology, 103: 99-108.

Tanirbergenov S I, Suleimenov B U, Saparov A S et al., 2016. The fertilizer system increasing the salt tolerance and productivity of cotton in the conditions of saline soils in southern Kazakhstan. Research Journal of Pharmaceutical Biological \& Chemical Sciences, 7(6): 147-155.

Thevs N, Ovezmuradov K, Zanjani L V et al., 2015. Water consumption of agriculture and natural ecosystems at the Amu Darya in Lebap Province, Turkmenistan. Environmental Earth Sciences, 73(2): 731-741.

Tilman D, Cassman K G, Matson P A et al., 2002. Agricultural sustainability and intensive production practices. Nature, 418(6898): 671-677.

Visser O, 2016. Running out of farmland? Investment discourses, unstable land values and the sluggishness of asset making. Agriculture \& Human Values: 1-14.

Vyshpolsky F, Qadir M, Karimov A et al., 2010. Enhancing the productivity of high-magnesium soil and water resources in Central Asia through the application of phosphogypsum. Land Degradation \& Development, 19(1): 45-56.

Xie G D, Qi W H, Zhang Y S et al., 1998. A study on utilization efficiency of main agricultural resources Resources Science, 20(5): 10-14. (in Chinese)

Zhang M, Chen Y N, Shen Y J et al., 2017. Changes of precipitation extremes in arid Central Asia. Quaternary International, 436: 16-27. doi:10.1016/j.quaint.2016.12.024.

Zhao F J, Ma Y, Zhu Y G et al., 2015. Soil contamination in China: Current status and mitigation strategies. Environmental Science \& Technology, 49(2): 750-759. 